\title{
Potenciais evocados auditivos de estado estável em crianças com perdas auditivas cocleares***
}

\author{
Auditory steady-state response in children with cochler hearing loss
}

\author{
Gabriela Ribeiro Ivo Rodrigues* \\ Dóris Ruthy Lewis**
}

\begin{abstract}
*Fonoaudióloga. Doutoranda do Programa de Estudos Pós-Graduados em Fonoaudiologia da Pontifícia Universidade Católica de São Paulo (PUC - SP). Endereço para correspondência: Centro "Audição na Criança" (CaAC) - Divisão de Educação e Reabilitação dos Distúrbios da Comunicação (Derdic) PUC - SP. Rua Estado de Israel, 860 - São Paulo - SP CEP 04022-040

(gabrielaivo@hotmail.com)
\end{abstract}

**Fonoaudióloga. Doutora em Saúde Pública pela Universidade de São Paulo (USP). Professora Titular do Programa de Pós-Graduação em Fonoaudiologia e Faculdade de Fonoaudiologia da PUC - SP.

***Trabalho Realizado no CeAC Derdic - PUC - SP.

Artigo Original de Pesquisa

Artigo Submetido a Avaliação por Pares

Conflito de Interesse: não

\begin{abstract}
Background: auditory steady-state response (ASSR) is indicated as a promising technique in the assessment of the hearing status of children. Aim: to investigate the level of agreement between the results of the ASSR and the visual reinforcement audiometry (VRA) in a group of children, thus examining the clinical applicability of this technique in hearing assessment of children. Method: participants were 14 children with ages between 4 and 36 months (mean 16 months) with the diagnosis of cochlear hearing loss. The ASSR was recorded in the frequencies of $0.5,1,2$ and $4 \mathrm{kHz}$ for multiple simultaneous stimulation and the results were compared with the visual reinforcement audiometry (VRA). Results: the intraclass correlation coefficients between ASSR and VRA were 0.90, 0.93, 0.93 and 0.89 respectively for the frequencies of 0.5, 1, 2 and $4 \mathrm{kHz}$, indicating a strong correlation between the techniques. Conclusion: the ASSR can provide accurate information to support the selection of hearing aids for children when it is not possible to perform the VRA.
\end{abstract}

Key Words: Auditory Evoked Potential; Hearing Loss; Children; Infants.

\section{Resumo}

Tema: os potenciais evocados auditivos de estado estável (PEAEE) têm sido apontados como uma técnica promissora na avaliação audiológica infantil. Objetivo: investigar o nível de concordância entre os resultados do PEAEE e a audiometria de reforço visual (VRA) em um grupo de crianças, averiguando assim a aplicabilidade clínica desta técnica na avaliação audiológica infantil. Método: foram avaliadas 14 crianças com idade entre 4 e 36 meses (média 16 meses) com diagnóstico de perda auditiva coclear. Os PEAEE foram registrados nas frequências de 0,5; 1; 2 e 4kHz pela estimulação múltipla simultânea, e os resultados obtidos foram comparados com os resultados da VRA. Resultados: os coeficientes de correlação intraclasse entre as respostas dos PEAEE e da VRA foram de 0,90; 0,93; 0,93 e 0,89 para as frequências de 0,$5 ; 1 ; 2$ e $4 \mathrm{kHz}$, respectivamente, indicando forte concordância entre as técnicas. Conclusão: os PEAEE podem fornecer informações precisas para que se possa dar início à seleção e adaptação dos AASI em crianças nas quais ainda não é possível a realização da VRA.

Palavras-Chave: Potencial Evocado Auditivo; Deficiência Auditiva; Criança.

Recebido em 13.03.2009.

Revisado em 08.12.2009; 13.01.2010;

18.01.2010.

Aceito para Publicação em 01.02.2010.

Referenciar este material como:

1 Rodrigues GRI, Lewis DR. Auditory steady-state response in children with cochler hearing loss (original title: Potenciais evocados auditivos de estado estável

$\sum 3$ em crianças com perdas auditivas cocleares). Pró-Fono Revista de Atualização Científica. 2010 jan-mar;22(1):37-42. 


\section{Introduction}

The success of early intervention for children with hearing loss depends on the evaluation techniques that may reflect accurate hearing thresholds before six months of age, for the adequate programming of hearing aids (HA) $(1,2)$.

Recently, the use of Auditory Steady-State Response (ASSR) has become an option for the objective evaluation of children's hearing before six months of age. The possibility to estimate hearing at multiple frequencies in both ears simultaneously $(3,4)$, to assess residual hearing in cases of profound hearing loss $(5,6)$, added to the automate detection of responses reducing the risk of subjective interpretation (7) are the advantages presented by the ASSR.

Several studies have showed a good applicability of ASSR to estimate hearing thresholds of children with different degrees of hearing loss, pointing it as a promising technique in the assessment of children's hearing $(1,2,5,6,8,9,10,11,12,13)$.

In this study, the first clinical experiences with ASSR in a high complexity hearing health service in Brazil will be addressed. The present study aimed to investigate the concordance level between the results from ASSR and from VRA in a group of children with sensorial hearing loss, thus verifying the clinical applicability of such technique in the assessment of children's hearing.

\section{Method}

This study was carried out in the "Children's hearing" Center - CeAC, of DERDIC - Divisão de Estudos e Reabilitação dos Distúrbios da Comunicação da Pontifícia Universidade Católica de São Paulo - PUC/ SP, and it was approved by the ethics committee of the institution (protocol $\left.n^{\circ} 113 / 2008\right)$. All carers of the involved subjects signed the Informed Consent Term allowing the performance and the publication of this research and its results, according to Resolution 196/ 96.

Fourteen children ranging in age from 04 to 36 months (mean age 16 months), totalizing 28 ears, took part in this research.

The inclusion criterion was the sensorial hearing loss diagnosis performed by the medical and audiological team of the institution. At the behavioral and electrophysiological assessments day, tympanometry was performed in order to exclude the possibility of middle ear affections. Children presenting abnormality in tympanometry were excluded from the study.

The VRA was performed in a soundproof room using an Interacoustics audiometer model AC-33, insertion phones model ER-3A, a visual reinforcement box with lighted figures, and some toys for the distraction technique. Aminimum response level(MRL) was investigated at the following frequencies: 0.5, 1, 2 and $4 \mathrm{kHz}$. The initial intensity tested was the one judged hearable by the child tested, and did not exceed $110 \mathrm{~dB}$ $\mathrm{HL}$ in all the frequencies. The MRL were researched in steps of $10 \mathrm{~dB}$ and confirmed in steps of $5 \mathrm{~dB}$. The stimulus used was the warble tone calibrated according to ISO 389-1 and ISO 389-2, and the behavioral MRL was the lowest intensity in which consistent responses were obtained and confirmed.

\section{Auditory Steady-State Response}

The equipment used was the Intelligent Hearing Systems (IHS), model "Smart EP".

Stimulus

Each stimulus consisted of a combination of four multiple and simultaneous tone pipes carrying the frequencies of $0.5,1,2$ and $4 \mathrm{kHz}$, at the modulation frequencies of approximately 77, 85, 93 and $101 \mathrm{~Hz}$ for the left ear and of 79, 87, 95 and $103 \mathrm{~Hz}$ for the right ear, respectively.

Recording

Exams were performed during natural sleep. Reference electrodes were placed at the right mastoid (A2) and at the left mastoid (A1), and active electrodes (Fz) and ground electrode (Fpz) were placed at the forehead. The MRL at 0,5, 1, 2 and $4 \mathrm{kHz}$ were researched simultaneously in both ears. The MRL were researched in steps of $10 \mathrm{~dB}$ and confirmed in steps of $5 \mathrm{~dB}$. The exam was stopped as responses were being observed and maintained with an electrical noise lower than 0.05 $\mu \mathrm{V}$. Each simultaneous multiple stimulus was presented bilaterally through insertion phones ER-3A. When it was not possible to test both ears, the test was performed monoaurally. The initial intensity was the one considered hearable by the subject according to the behavioral assessment, and it did not exceeded 110 dBSPL.

Analysis

The maximum number of stimuli was adjusted to 400 sweeps during 1.024 s each, divided in 20 screenings of 20 sweeps each one. The EEG samples collected after 20 sweeps, that is, one screening, were used with a filter of $30-3000 \mathrm{~Hz}$, amplified with a gain of $1000.0 \mathrm{~K}$, and then processed using a conversion rate A/D of 20 $\mathrm{kHz}$. After each screening, the Fourier's Rapid 
Transformation(FRT) was performed automatically by the software, showing the result obtained in a polar plot and in a frequency spectrum. The F test calculated the probability of the response be significantly different than the mean amplitude of the background noise at the modulation frequency, as well as the mean amplitude of the background noise in the side bins. When the sign-to-noise ratio was higher than $6.13 \mathrm{~dB}(\mathrm{p}=0.05)$ in both conditions, the sign was considered a response $(12,14)$.

Results conversion

Results of ASSR were transformed from dB SPL to HL according to ISO 389-2 for insertion phones, with corrections of $-6,-0,-3$ and $-6 \mathrm{~dB}$ for tones of $0.5,1,2$ and, respectively - criterion used in a previous study (12) with the same equipment.

Results Analysis

Dispersion diagram were built representing the lines whose dots correspond to equal response in both tests, and the concordance between results from ASSR and from VRA was analyzed using the intraclass correlation coefficient(15)

\section{Results}

Eight children allowed the performance of VRA with insertion phones enabling the assessment of both ears separately. Six children did not allow the placement of insertion phones and the VRA was performed in free field. In those cases, results were compared to the MRL of the ASSR in the best ear.

Cases who didn't present response in the maximum intensity tested were excluded from the comparison. In the end, $60 \mathrm{MRL}$ in VRA were compared to their respective pairs of ASSR: 21 pair for $0.5 \mathrm{kHz}, 17$ for 1 $\mathrm{kHz}, 12$ for $2 \mathrm{kHz}$ and 10 pairs for $4 \mathrm{kHz}$.

The mean difference and the standard deviation between both exams for frequencies of 0.5, 1, 2 and 4 $\mathrm{kHz}$ are presented in Table 1.

The intraclass correlation coefficients between the MRL of ASSR were 0.90, 0.93, 0.93 and 0.89 for 0.5, 1, 2 and $4 \mathrm{kHz}$, respectively, indicating strong concordance between the techniques. The dispersion diagrams presented in Graph 1 show a linear relation between the MRL in ASSR and in VRA; it's possible to observe that the dots are distributed uniformly around the line which represents the point in which the MRL in ASSR is the same as the MRL in VRA at all frequencies.

Figure 1 shows typical examples of how the ASSR could estimate behavioral responses in children with sensorial hearing loss assessed in this study.

The four audiograms illustrated on the top of Figure 1(PartA) show the relationASSR $x$ VRAin the different degrees of hearing loss. The four audiograms on the bottom of Figure 1 (Part B) show some cases in which the MRL in ASSR were better than the behavioral responses.

TABLE 1. Mean difference and standard deviation between ASSR (dB HL) and VRA (dB HL)

\begin{tabular}{cccc}
\hline Frequency (Hz) & N & Difference & Standard deviation \\
\hline 500 & 21 & $-1,7$ & 8,8 \\
1000 & 17 & 1,5 & 6,6 \\
2000 & 12 & $-0,1$ & 6,9 \\
4000 & 10 & $-4,5$ & 7,5 \\
\hline
\end{tabular}

Legend: ASSR - Auditory Steady-State Response; VRA - Visual Reinforcement Audiometry; dB HL - Decibel Hearing Level; Hz -

Hertz. 
GRAPH 1. Dispersion diagram of MRL (dB HL) in ASSR and in VRA at the frequencies of $500 \mathrm{~Hz}, 1000 \mathrm{~Hz}, 2000 \mathrm{~Hz}$ and $4000 \mathrm{~Hz}$.

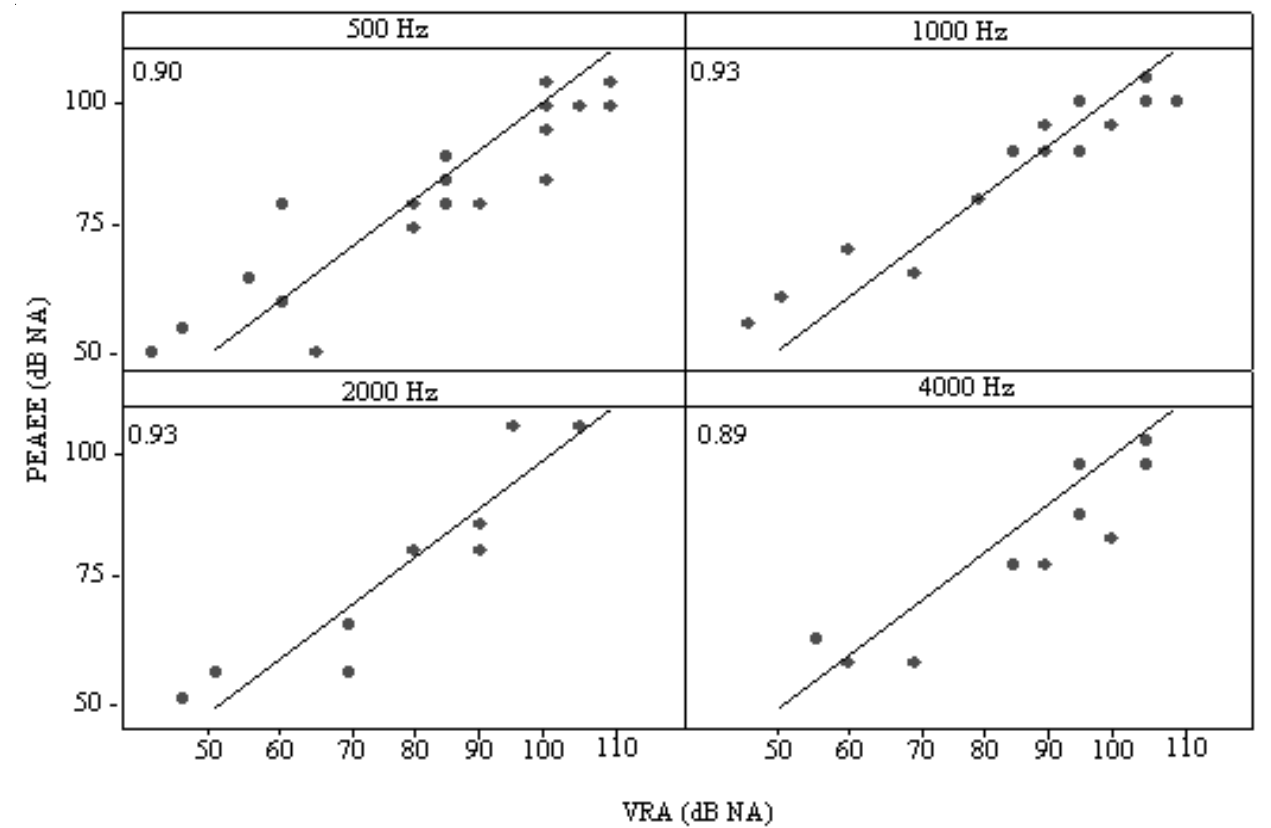

Legend: ASSR - Auditory Steady-State Response; VRA - Visual Reinforcement Audiometry; dB HL - Decibel Hearing Level; Hz - Hertz.

\section{Discussion}

The results presented in this paper indicate that there is a strong concordance between results from ASSR and from VRA in children with sensorial hearing loss. Such results are consistent with the ones reported previously in studies with babies and children with sensorial hearing loss who performed ASSR with simple stimulation $(5,8,9,16,17,18,19)$. And also with studies $(1,2,12,20)$ that used multiple stimulation.

Studies indicate that, either using simple stimulation $(5,10,17,18)$, or multiple stimulation (2), the difference between the MRL in ASSR tends to be lower as the degree of hearing loss is higher, as it also happens with the increase of the carrier frequency. In the present study, due to the reduced number of cases it was not possible to statistically verify this fact. However, observing the audiograms of Figure 1 - Part A carefully, it is possible to note such relation.

In general, the mean differences between the MRL in both techniques were between 2 and $4 \mathrm{~dB}$, in agreement with the findings reported by Luts et al. (1). Literature points to a great variability among studies: Aoyagi, Kiren and Furuse (16) reported differences from 4 to $16 \mathrm{~dB}$, with standard deviations between 2 and 15; Rance and Briggs (17) found standard deviations varying from 6 to $17 \mathrm{~dB}$ depending on the degree of hearing loss; and Swanepoel, Hugo and Roode (10) observed differences from 4 to $8 \mathrm{~dB}$, with standard deviations from 8 to $12 \mathrm{~dB}$.

In this study, the greater mean difference was at 4 $\mathrm{kHz}$, while several studies reported greater difference at the frequency of $0.5 \mathrm{kHz}$, due to the cochlear tonotopy $(5,9,10,12)$. Luts and Wouters (23) reported greater differences not only at $0.5 \mathrm{kHz}$, but also at 4 $\mathrm{kHz}$, although the standard deviations observed were similar in all frequencies, as observed in the present study.

In some cases, the difference between the MRL in ASSR and in VRA resulted in a negative value (see Table 1). This indicates that, at some point, the MRL in ASSR were better than the MRL in VRA. These findings were also reported in other studies that compared ASSR with VRA $(8,12)$. It is well established that the electrophysiological MRL are above the behavioral thresholds (21). However, hearing responses in babies and children based on VRA are variable, once in the behavioral assessment the MRL obtained are more elevated than the real hearing thresholds given the maturation of responses with the development of auditory and motor skills (12).

There are reports that the MRL obtained with the VRA in children from 6 to 12 months of age were from 10 to $15 \mathrm{~dB}$ worse than the ones obtained in older children and adults (12). This may explain why in some cases of the present study the MRL in ASSR were superior than the those in VRA, as it may be observed in the audiograms of Figure 1 - Part B.

Despite such variables, the VRA responses included in this study were consistent and its strong correlation with the ASSR indicates that when it is not possible yet to perform VRA, the ASSR may provide precise information for the selection and adaptation of HA. 
FIGURE 1. Examples of cases of comparison ASSR x VRA at the frequencies of $500 \mathrm{~Hz}, 1000 \mathrm{~Hz}, 2000 \mathrm{~Hz}$ and $4000 \mathrm{~Hz}$.
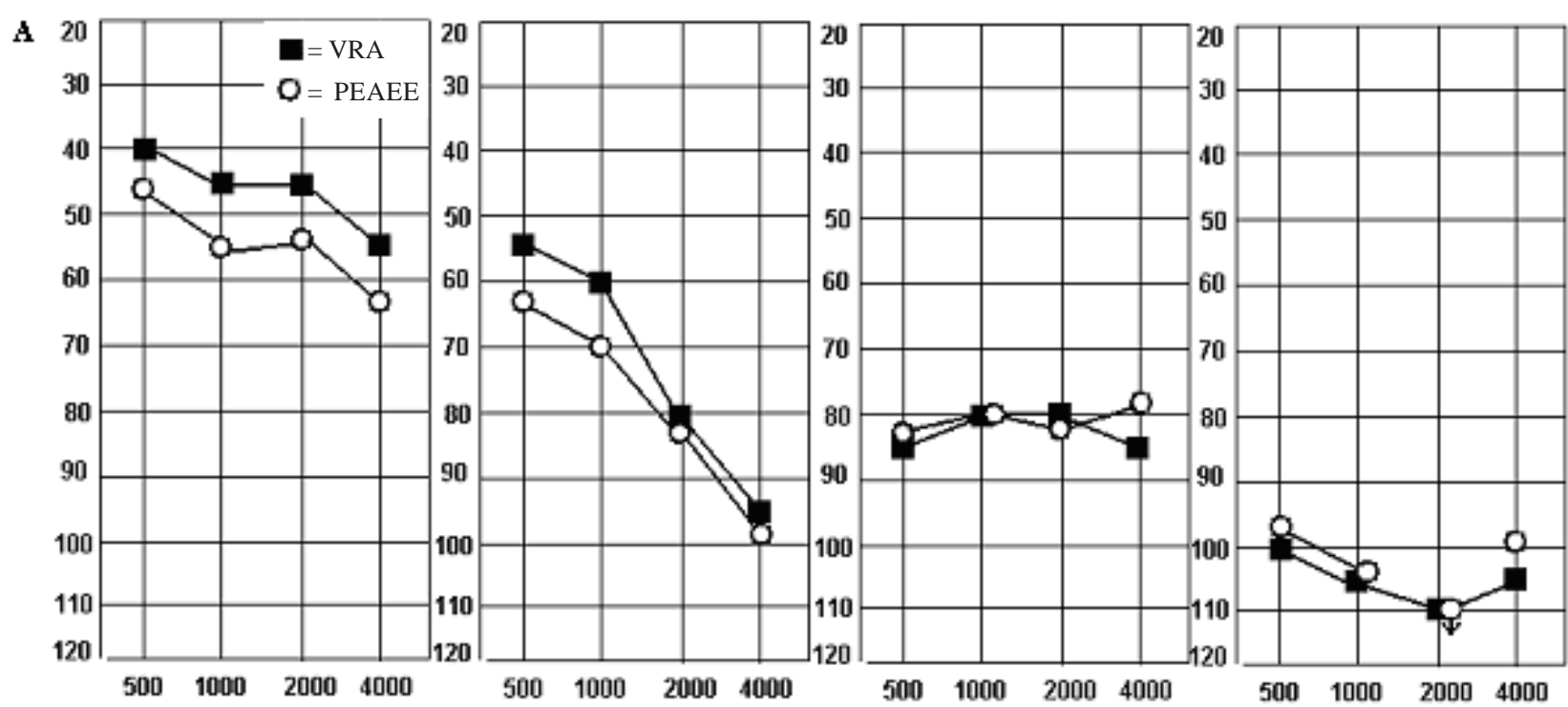

$\mathbf{B}$
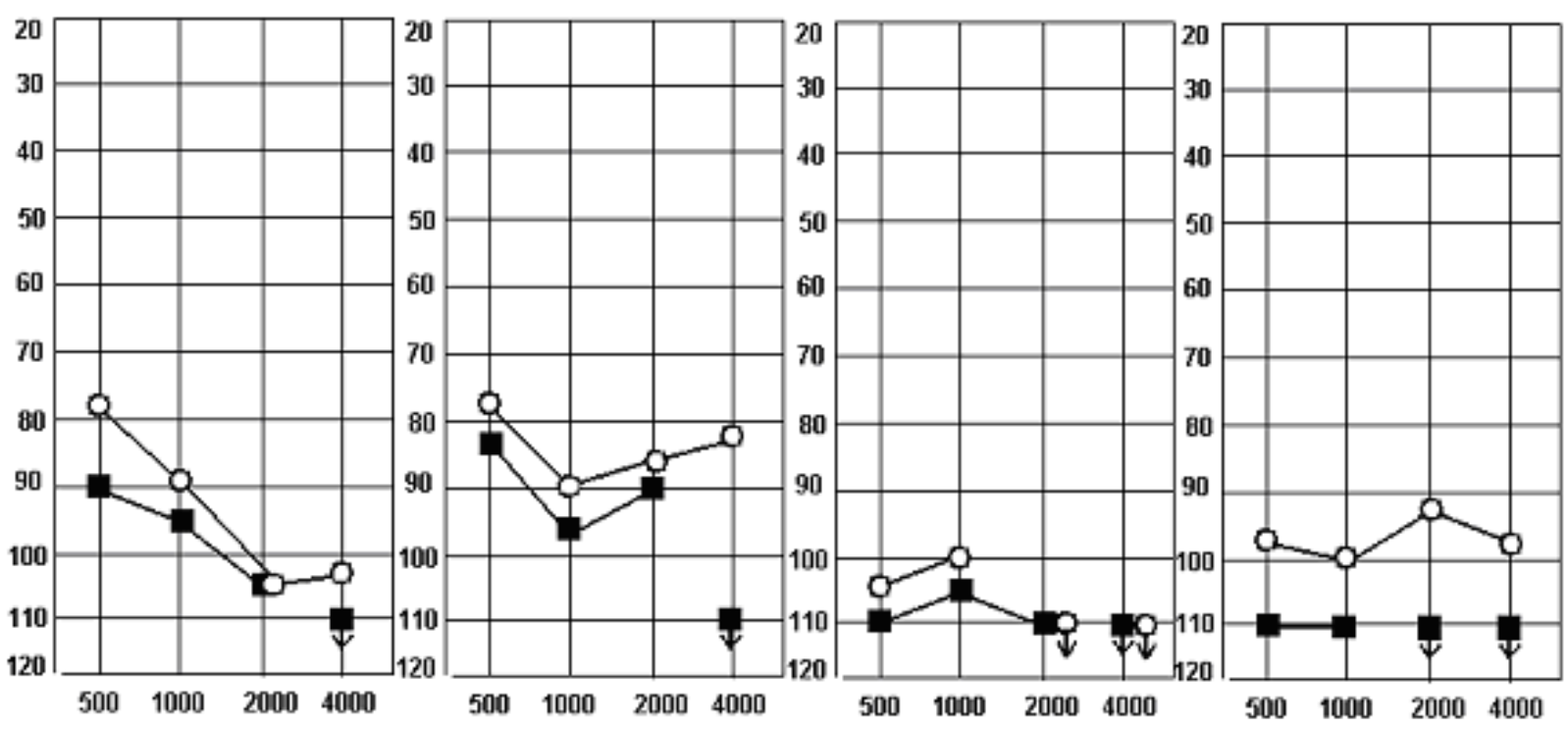

Legend: ASSR - Auditory Steady-State Response; VRA - Visual Reinforcement Audiometry; A- Relation ASSR x VRA in the different degrees of hearing loss. B- Cases in which the ASSR were better than VRA responses

Nevertheless, the possibility of having a hearing estimative does not diminish the importance of the behavioral assessment. The use of evoked potentials is very useful for the conclusion of diagnosis in this age group, although the behavioral audiometry is still the gold-standard in childhood assessment $(8,12,17)$.

A subjective test, however, is particularly difficult when a patient is a very small child. A method capable of providing objective hearing thresholds by frequency specificity becomes necessary for this population. Strongly correlated to the VRA in this study, the ASSR was capable to perform an important role in the assessment of children who cannot respond to behavioral assessment with conditioning procedures $(1,12)$.

Thus, the use of ASSR in the first years of life may provide information that will enable the audiologist to perform selection and adaptation of HA more precisely, assuring the early intervention and, therefore, minimizing delays in speech and language development caused by a congenital hearing loss (1, $5,6,9,12,17)$. 


\section{Conclusion}

This study with 14 children with sensorial hearing loss allowed to conclude that there is a strong concordance between ASSR and VRA responses, indicating that the ASSR may provide precise information for the selection and adaptation of HA in children who are not yet able to perform VRA.

\section{References}

1. Luts H, Desloovere C, Kumar A, Vandermeersch E, Wouters J. Objective assessment of frequency-specific hearing thresholds in babies. Int J Pediatr Otorhinolaryngol. 2004; 68(7):915-26.

2. Rance G, Roper R, Symons L, Moody LJ, Poulis C, Dourlay $\mathrm{M}$, et al. Hearing threshold estimation in infants using auditory steady-state responses. J Am Acad Audiol. 2005; 16(5):291-300.

3. Lins OG, Picton TW. Auditory steady-state responses to multiple simultaneous stimuli. Electroencephalogr Clin Neurophysiol. 1995;96(5):420-32.

4. John MS, Purcell DW, Dimitrijevic A, Picton TW: Advantages and caveats when recording steady-state responses to multiple simultaneous stimuli. J Am Acad Audiol. 2002; 13:246-59.

5. Rance G, Dowell RC, Rickards FW, Beer DE, Clark GM. Steady-state evoked potential and behavioral hearing thresholds in a group of children with absent clique-evoked auditory brain stem response. Ear Hear. 1998;19(1):48-61.

6. Vander Werff KR, Brown CJ, Gienapp BA, Schmidt Clay KM. Comparison of auditory steady-state response and auditory brainstem response thresholds in children, J. Am. Acad. Audiol. 2002;13:227-35.

7. Lins OG, Picton TW, Boucher BL, Durieux-Smith A, Champagne SC, Moram LM, et al. Frequency-specific audiometry using steady-state responses. Ear Hear. 1996; 17(2):81-96.

8. Cone-Wesson B, Dowell RC, Tomlin D, Rance G, Ming WJ. The auditory steady-state response: comparisons with the auditory brainstem response. J. Am. Acad. Audiol. 2002; 13(4):173-87.

9. Stueve MP, O'rourke C. Estimation of hearing loss in children: comparison of auditory steady-state response, auditory brainstem response, and behavioral test methods. Am J Audiol. 2003;12(2):125-36.

10. Swanepoel D, Hugo R, Roode R. Auditory Steady-State response for children with severe to profound hearing loss. Arch Otolaryngol Head Neck Surg. 2004;130:531-35.

11. Firszt JB, Gaggl W, Runge-Samuelson CL, Burg LS, Wackym A. Auditory sensitivity in children using the auditory steady-state response. Arch Otolaryngol Head Neck Surg. 2004; 130:536-40.

12. Han D, Mo L, Liu H, Chen J, Huang L. Threshold estimation in children using auditory steady-state responses to multiple simultaneous stimuli. ORL J Otorhinolaryngol Relat Spec. 2006;68(2):64-8.
13. Duarte JL, Alvarenga KF, Garcia TM, Costa Filho OA, Lins OG. Auditory steady-state response in the auditory evaluation: clinical application (original title: A resposta auditiva de estado estável na avaliação auditiva: aplicação clínica). Pró-Fono R At Ci. 2008;20(2):105-10.

14. Mo L, Stapells DR. The effect of brief-tone stimulus duration on the brain stem Auditory Steady-State Response. Ear Hear. 2008;29:121-33.

15. Fleiss JL. The design and analysis of clinical experiments. New York: John Wiley and Sons; 1986.

16. Aoyagi M, Kiren T, Furuse H: Pure-tone threshold prediction by $80 \mathrm{~Hz}$ amplitude-modulation following response. Acta Otolaryngol Suppl. 1994;511:7-14.

17. Rance G, Briggs RJS. Assessment of hearing in infants with moderate to profound impairment: the Melbourne experience with auditory steady-state evoked potential testing. Ann Otol Rhinol Laryngol Suppl. 2002;189:22-8.

18. Rance G, Rickards F. Prediction of hearing threshold in infants using auditory steady-state evoked potentials. J Am Acad Audiol. 2002;13(5):236-45.

19. Swanepoel D, Schmulian D, Hugo R. Establishing normal hearing with the dichotic multiple-frequency auditory steadystate response compared to an auditory brainstem response protocol. Acta Otolaryngol. 2004;124:62-8.

20. Perez-Abalo MC, Savio G, Torres A, Rodríguez E, Galan L: Steady-state responses to multiple amplitude-modulated tones: an optimized method to test frequency-specifi c thresholds in hearing-impaired children and normal-hearing subjects. Ear Hear. 2001;22:200-211.

21. Stapells DR. Frequency-specific evoked potential audiometry in infants. In: Seewald, RC. A sound foundation through early amplification. Chicago: Phonak; 2000. p. 13-31.

22. Nozza RJ, Wilson WR: Masked and unmasked pure-tone thresholds of infants and adults: development of auditory frequency selectivity and sensitivity. J Speech Hear Res. 1984;27:613-22.

23. Luts $H$, Wouters J. Hearing assessment by recording multiple auditory steay-state responses: the influence of test duration. Int J Audiol. 2004;43:471-78. 